Volume: 11 Issue: 1 Year: 2014

\title{
The internal consistency reliability and construct validity of the Turkish translation of the beliefs about appearance scale
}

\author{
Emine Göçet Tekin \\ Tayfun Doğan ${ }^{2}$
}

\begin{abstract}
The aim of this study was to adapt into Turkish and examine the psychometric properties of the Beliefs about Appearance Scale (BAAS), which was developed by Spangler and Stice (2001) in order to measure the beliefs about appearance. The participants of the study were 274 current Sakarya University students. In this study, the psychometric properties of the scale were examined by means of item analysis, exploratory factor analysis, criterion-related validity, internal consistency and split-half reliability methods. The findings have confirmed that BAAS was a sufficiently valid and reliable measuring instrument.
\end{abstract}

Keywords: Appearance; Beliefs; Validity; Reliability

\section{Introduction}

According to cognitive therapy theory, early childhood experiences have an impact on the development of cognitive schemas and automatic thoughts. In the next periods of life, these basic beliefs shape the individuals' cognitions of and beyond themselves. However, by losing functionality in time, these basic beliefs developed in early childhood might be the basis of psychological problems (Sungur, 1994). These dysfunctional beliefs which are acquired by social experiences are strict, resistant to change, based on generalizations, not realistic thoughts and they prevent the individual to perform well ( Savaşır and et.al, 1996; Young, 1994 ). Beck indicated that these dysfunctional thoughts and beliefs might be related to the individual himself/herself, outer world and future, and said that these schemas are underlying reasons of depression (Beck and et.al,

\footnotetext{
${ }^{1}$ Instructor, Sakarya University Department of Foreign Languages, egocet@sakarya.edu.tr

2 Assistant Professor Doctor, Niğde University Faculty of Education, Department of Psychological Counselling and Guidance, tayfun@,tayfundogan.net
} 
Tekin Göçet, E., \& Doğan, T. (2014). The internal consistency reliability and construct validity of the Turkish translation of the beliefs about appearance scale. International Journal of Human Sciences, 11(1), 1178-1187. doi: $\underline{10.14687 / \text { ijhs.v11i1.2910 }}$

1979 ). Beliefs about appearance are also considered as the dysfunctional thoughts about the individual's body and appearance. These thoughts are related with the impact of social communication with the individual's body type, attractiveness, weight, height and appearance. When literature is reviewed, in order to assess the cognitive processes about appearance, the Appearance Schemas Inventory has been developed (Cash and Labarge, 1996) and then revised (Cash and et.al, 2004).

BAAS is a unidimensional, self-report style, 20-item scale which was developed by Spangler and Stice (2001) in order to measure the dysfunctional thoughts and beliefs about appearance. The items of the scale consist of statements which tell the importance and meaning of the individual's appearance and its impact on his / her life and relations with other people. It is a 5 point Likert scale ranging from (0) Not at all and (4) Extremely. The higher the score, the more the person was considered to have dysfunctional thoughts about his/her appearance. The Psychometric Properties of BAAS was examined by analyzing data gathered from three different samples. The first group includes 462 university students (\%53 female/ \%47 male) from four different universities in Utah and Boston, the USA. The second group consists of 231 adolescent female students of a College in California. And the third group includes 117 females from California and Texas. The factor structure of the scale was examined starting with the data gathered from the females in the first group and single factor model accounting for the $\% 52$ of the total variance was found. The factor loadings of the items were between .54 and .85. The confirmatory factor analysis was performed for four different groups - male and females from the first group, the second and the third groupconfirming the single factor structure of the scale. Cronbach's $\alpha$ internal consistency of the BAAS for three different groups was found as $.94, .95$ and .96 respectively. In order to determine the 10month test-retest reliability coefficient of the scale, the form was applied to 219 students from the second group and $r=.73, p<.001$ the correlation was found to be $\mathrm{r}=.73, p<.001$. When it was applied to 115 students from the third group within three weeks test-retest reliability coefficient of the scale was found to be $r=.83, p<.001$. The discriminative and concurrent validity of the scale was evaluated by comparing the scale with scales on body image, appearance, physical health and eating disorders and validity supportive and statistically significant relations were found.

\section{Purpose}

The aim of this research was to examine the validity and reliability of the BAAS on the sample of Turkish university students. When the literature was reviewed in spite of the existence of the 
Tekin Göçet, E., \& Doğan, T. (2014). The internal consistency reliability and construct validity of the Turkish translation of the beliefs about appearance scale. International Journal of Human Sciences, 11(1), 1178-1187. doi: $\underline{10.14687 / \text { ijhs.v11i1.2910 }}$

various measuring instruments for body image and appearance in our country, the non-existence of an instrument for dysfunctional thoughts and beliefs about appearance was seen as a need for this study.

\section{Methodology}

\subsection{Participants}

The participants in this study were 274 (144 female, 112 male and 18 not mentioned) university students from different faculties and departments of Sakarya University in 2009-2010 academic year. The age range of the sample was 18 to 30 years, with a mean age of 20.09 (SD=1.96).

\subsection{Instruments}

3.2.1. Social Appearance Anxiety Scale (SAAS) (Hart and et al., 2008) was developed to measure the emotional, cognitive and behavioral anxiety about being negatively evaluated by others because of one's overall appearance. It is a 16-item, 5 point Likert type Scale. The adaptation of the scale into Turkish was carried out by Doğan (2010). The structure validity of the scale was examined by using confirmatory factor analysis and exploratory factor analysis. Exploratory factor analysis revealed a single-factor structure explaining the $\% 53.4$ of the total variance. The factor loadings of the scale ranged from .35 and .87 . Result of confirmatory factor analysis showed that the minimum value of chi-square was $\left(\chi^{2}=143.79, \mathrm{~N}=254, \mathrm{p}=0.01\right)$. Goodness-of-fit indices were found to be as RMSEA $=0.051, \mathrm{NFI}=0.98, \mathrm{CFI}=0.99, \mathrm{IFI}=0.99, \mathrm{RFI}=0.98, \mathrm{GFI}=0.93$ and $\mathrm{AGFI}=0.90$. It was observed that the goodness-of- fit indices were sufficient. The internal consistency coefficient was 93. The split half reliability coefficient was .88. The test-retest reliability which was conducted on 86 participants was found to be .85 .

3.2.2. Rosenberg Self Esteem Scale (RSES) (Rosenberg, 1965) the scale is a 10-item, Likert scale with items answered on a four point scale. The adaptation into Turkish and psychometric evaluation of the scale were carried out by Çuhadaroğlu (1986) and the internal consistency of the scale was found to be .75 . In a study conducted by Çeçen (2008) the internal consistency of the scale was found as .82. In another study conducted by Atlı and et. al. (2009) it was found as .86.

3.2.3. Zung Self-Rating Depression Scale (ZSDS) The scale is a 20 -item scale, designed by Zung (1965). The psychometric properties of the scale were examined on a sample of Turkish 
Tekin Göçet, E., \& Doğan, T. (2014). The internal consistency reliability and construct validity of the Turkish translation of the beliefs about appearance scale. International Journal of Human Sciences, 11(1), 1178-1187. doi: $\underline{10.14687 / \text { ijhs.v11i1.2910 }}$

students by Gençdoğan (2001). In order to show the criterion-related validity of the scale Beck Depression Inventory and Symptoms Check List (SCL-R-90) Depression Subscale were used. The correlation coefficient between ZSDS and BDI and between ZSDS and SCL-R-90 was found as .89 and .81 respectively. The Cronbach's alpha of the scale was .80 .

\section{Results}

\subsection{Translation Process}

In the translation process of BAAS's original language, which is English, to Turkish language, the 'back translation' method was used. According to this, the scale was translated by three associates separately, one of them was from the Department of Psychological Counseling and the two of them were from the Department of Foreign Languages. The obtained results were analyzed, the items that were thought to ideally represent the expressions in the original form were taken and the Turkish form was prepared. This Turkish form was re-translated by an associate from the Department of Foreign Languages and the items that were thought to have loss in meaning were revised. By deciding that the translation form was equivalent to the original form, it took its final form to apply.

\subsection{Item Analysis}

An item analysis was performed in order to determine the questionnaire items' power of predicting the total score. The correlation coefficient indicated the coherence of each item with the overall scale. In the interpretation of item total correlation, the items whose rates were .30 and above were accepted as sufficient (Büyüköztürk, 2004). At the end of the analysis, it was seen that the item total correlations on these items were between .42 and .67. In order to determine the distinctiveness of the items, the upper and lower \% 27 group means were made. Accordingly, it was concluded that all the differences between item mean scores were meaningful. This result indicated that each item was adequately distinctive. The results were presented in the Table-1. 
Tekin Göçet, E., \& Doğan, T. (2014). The internal consistency reliability and construct validity of the Turkish translation of the beliefs about appearance scale. International Journal of Human Sciences, 11(1), 1178-1187. doi: 10.14687/ijhs.v11i1.2910

Table-1 The Item Total Correlation of BAAS and t-test results of the differences between upper and lower $\% 27$ group means

\begin{tabular}{|c|c|c|c|}
\hline & Items & $\begin{array}{l}\text { Item-Total } \\
\text { Correlations }^{1}\end{array}$ & $\begin{array}{c}t \\
(\text { Upper \%27- } \\
\text { Lower\%27) }\end{array}$ \\
\hline Item1 & & .42 & 7.671* \\
\hline Item2 & & .51 & $9.317^{*}$ \\
\hline Item3 & & .49 & $8.168^{*}$ \\
\hline Item 4 & & .49 & 7.761* \\
\hline Item5 & & .57 & $9.544^{*}$ \\
\hline Item6 & & .49 & $9.647 *$ \\
\hline Item7 & & .57 & $12.805^{*}$ \\
\hline Item8 & & .65 & $12.696^{*}$ \\
\hline Item9 & & .62 & $10.969 *$ \\
\hline Item10 & & .64 & $10.938 *$ \\
\hline Item11 & & .62 & $10.185^{*}$ \\
\hline Item12 & & .66 & $14.233^{*}$ \\
\hline Item13 & & .65 & $12.979 *$ \\
\hline Item14 & & .56 & $10.930 *$ \\
\hline Item15 & & .62 & $11.567^{*}$ \\
\hline Item16 & & .65 & $12.186^{*}$ \\
\hline Item17 & & .64 & $13.480^{*}$ \\
\hline Item18 & & .67 & $14.078^{*}$ \\
\hline Item19 & & .55 & $11.565^{*}$ \\
\hline Item20 & & .65 & 13.494* \\
\hline
\end{tabular}

\subsection{Structure Validity}

4.3.1. Exploratory Factor Analysis ( EFA ) : In order to determine the structure validity of BAAS, EFA was conducted. Whether the data had the adequate criteria, in other words whether 
Tekin Göçet, E., \& Doğan, T. (2014). The internal consistency reliability and construct validity of the Turkish translation of the beliefs about appearance scale. International Journal of Human Sciences, 11(1), 1178-1187. doi: $\underline{10.14687 / \text { ijhs.v11i1.2910 }}$

the data were available for factor analysis was examined with Kaiser-Meyer-Olkin (KMO) coefficient and Barlett Sphericity test. For the availability of the data KMO had to be above .60 and Barlett test had to be statistically meaningful (Büyüköztürk, 2004). KMO was .90 and Barlett Sphericity test was $\chi^{2}$ and its rate was $2717.896, \mathrm{sd}=190, p<.001$. These findings indicated that the data were available for factor analysis and the scores were normal. In EFA, without any limitations, principle component analysis and unrotated method were used initially and in the end, 4 factors whose values were above 1 and which explained \%62.22 of total variance was obtained. However, when screen plot was examined (see Figure 1) after the first factor a fracture was observed. Therefore, considering that the original form had a single factor it was concluded that the scale items had focused on a single factor and EFA was repeated by a single factor limitation. At the end of the analysis, a single-factor structure whose eigenvalue was 8.1 and which explained $\% 40.92$ of total variance was obtained. The factor loads of the items were given in the Table- 2 .

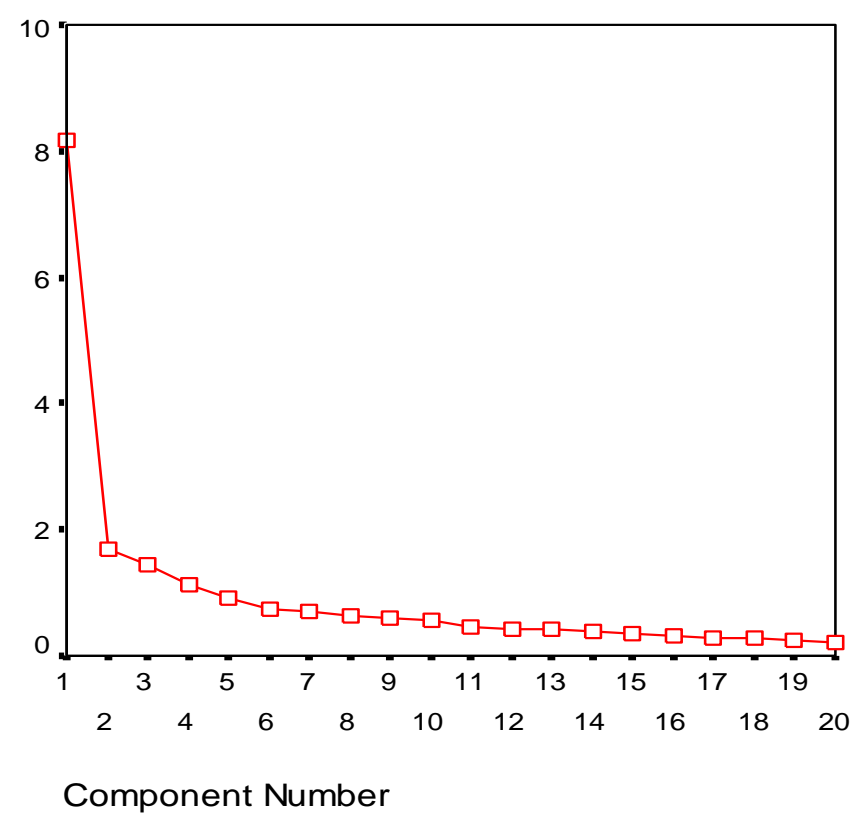

Figure1. Screen Plot 
Tekin Göçet, E., \& Doğan, T. (2014). The internal consistency reliability and construct validity of the Turkish translation of the beliefs about appearance scale. International Journal of Human Sciences, 11(1), 1178-1187. doi: $\underline{10.14687 / \text { ijhs.v11i1.2910 }}$

Tablo-2. Exploratory Factor Analysis of BAAS and Factor Loadings

\section{Loadings}

1. Başkalarının benim hakkımdaki düşünceleri görünüşüme dayalıdır.

2. Diğer insanlar üzerindeki etkim nasıl göründügüume bağlıdır.

3. Eğer en iyi şekilde görünmezsem insanlar benim hakkımda daha az olumlu düşünür.

4. Eğer daha iyi görünseydim insanlar benimle daha çok ilgilenirlerdi.

5. Eğer istediğim gibi görünüşe sahip olsaydım insanlarla ilişkilerim daha iyi olurdu.

6. İşimde ya da kariyerimde ne kadar başarılı olacağım büyük oranda nasıl göründüğüme bağlıdır.

7. Görünüşüm işleri yapabilme becerimi etkiler.

8. Nasıl göründügüm etkinliklerdeki (örn. Okul, iş, hobiler vs.) performansımı etkiler.

9. Karşıma çıkan firsatlar görünüşüme bağlıdır.

10. Eğer istediğim gibi görünüşe sahip olsaydım okul ve iş performansım artar, firsatlar çoğalırdı.

11. Birey olarak benim değerim nasıl göründüğüme bağlıdır.

12. Kendimle ilgili nasıl hissettiğim büyük ölçüde görünüşüme bağlıdır.

13. İstediğim gibi bir görünüşüm olsaydı kendimle ilgili daha olumlu düşünürdüm.

14. Nasıl göründüğüm kim olduğumun önemli bir parçasıdır.

15. En iyi şekilde görünmediğim sürece kendimle ilgili iyi hissetmem zordur.

16. Kendimi mutlu hissetmem nasıl göründüğüme bağlıdır.

17. Görünüşümün düzelmesi, bir şeyleri başarmışım gibi beni iyi hissettiren birkaç durumdan biridir.

18. Eğer görünüşüm iyi olsa hayat benim için daha heyecanlı veya ödüllendirici olacaktır.

19. Nasıl göründüğüm ruh halimi etkiler.

20. Eğer istediğim gibi bir görünüşe sahip olsaydım hayattan daha çok keyif alırdım. 
Tekin Göçet, E., \& Doğan, T. (2014). The internal consistency reliability and construct validity of the Turkish translation of the beliefs about appearance scale. International Journal of Human Sciences, 11(1), 1178-1187. doi: $\underline{10.14687 / \text { ijhs.v11i1.2910 }}$

\subsection{Criterion-Related Validity}

To determine the criterion-related validity of BAAS, the relation between BAAS and some measuring instruments which measure similar and different structures was investigated. Accordingly, with BAAS, Social Appearance Anxiety Scale - SAAS (Doğan, 2010), Rosenberg SelfEsteem Scale- RSES (Rosenberg, 1965) and Zung Depression Scale - ZSDS (Zung, 1965) were conducted on 98 students. Theoretically, it was expected that the correlation with BAAS and SAAS, ZSDS would be positive; the correlation with BAAS and RSES would be negative. At the end of the analysis, the correlation with BAAS and SAAS was positive $(\mathrm{r}=.46, p<.001)$ as expected. The correlation with BAAS and ZSDS was positive $(\mathrm{r}=.27, p<.001)$ as well. The correlation with BAAS and RSES had a negative correlation $(\mathrm{r}=.-38, p<.001)$. These findings were the supporting proofs of the validity of BAAS.

\subsection{Reliability}

The reliability of BAAS was examined by internal consistency coefficient and split-half methods. Cronbach alfa coefficient was .92. The reliability coefficient which was obtained by split-half method was .85 . These results indicated that the reliability level of the scale was adequate.

\section{Discussion and Conclusion}

The purpose of this study was to adapt BAAS which was developed by Spangler and Stice (2001) and examine its psychometric characteristics. Initially the scale was translated into Turkish and by back translation method language equivalency was obtained.

In order to provide the representativeness of the scale items, item total correlation was examined by item analysis. Accordingly, there was no need to put aside any of the items by seeing that all the items had the load of .30 and above. To indicate the distinctiveness of the items, upper and lower \% 27 group means were compared. The analysis showed that the differences between the items mean scores were all meaningful. This result led to the fact that the distinctiveness level of the scale items was adequate.

EFA was carried out in order to determine the structure validity of BAAS. To determine the criterion-related validity of BAAS, the relation between BAAS and SAAS, RSES and ZSDS was examined. The percent of total variance explained by this single factor was $\% 40.92$. Factor loadings ranged between .46 and .72 . The relation between BAAS and SAAS was found to be positive while the relation between BAAS and RSES was found to be negative. Social appearance anxiety is 
Tekin Göçet, E., \& Doğan, T. (2014). The internal consistency reliability and construct validity of the Turkish translation of the beliefs about appearance scale. International Journal of Human Sciences, 11(1), 1178-1187. doi: $\underline{10.14687 / \text { ijhs.v11i1.2910 }}$

considered to be one's anxiety related to his/her appearance (Doğan, 2010). In this respect, the positive relation between BAAS and ZSDS is not surprising when we assume that depression is originated from dysfunctional beliefs and thoughts. The relation with BAAS and RSES had a negative correlation. It was an expected result because having dysfunctional beliefs and thoughts about appearance might be a determinant of dissatisfaction with one's self and body. All these findings indicate that the scale is adequately valid.

The reliability of the scale was examined through internal consistency and split half methods. The Cronbach alfa coefficient was .92 and split half reliability coefficient was found to be .85 . And these results also indicate that the scale is adequately reliable.

As a result, the Turkish version of BAAS can be said to be a valid and reliable scale that can be used to measure the beliefs about appearance. In this study, the reliability of the scale was examined through internal consistency and split half methods. In later studies, the test-retest reliability can also be examined in order to establish the stability of the scale over time. Moreover, the factor structure of the scale can be examined on a wide variety of samples. The relationship between BAAS and measuring instruments of eating disorders and social anxiety can be examined as well. And whether it predicts eating disorders and social anxiety can be analyzed.

\section{References}

Atlı, Z., Eskin, M., ve Dereboy, Ç. (2009). İntihar olasılluğ1 ölçeğinin klinik örneklemde geçerlik ve güvenirliği. Klinik Psikijatri, 12,111-124.

Beck, A. T., Rush, J., Shaw, B. F. ve Emery, G. (1979). Cognitive therapy of depression. The Guildford Press, New York.

Büyüköztürk Ş. (2004). Veri analiæi el kitabı. Ankara, Pegem A Yayıncıllk, 2004.

Büyüköztürk Ş., Akgün E.Ö., Özkahveci Ö., \& Demirel, F. (2004). Güdülenme ve öğrenme stratejileri ölçeğinin Türkçe formunun geçerlik ve güvenirlik çalısması. Kuram ve Uygulamada Eğitim Bilimleri Dergisi, 4 (2), 207-239.

Cash, T. F., Melnyk, S. E. ve Hrabosky, J. I. (2004). The assessment of body image investment: An extensive revision of the appearance schemas inventory. The international Journal of Eating Disorders, 35(3), 305-316.

Cash, T. F., \& Labarge, A. S. (1996). Development of the Appearance Schemas Inventory: A new Cognitive Body-image Assessment. 20(1), 37-50.

Çeçen, A. R. (2008). Üniversite öğrencilerinde yaşam doyumunu yordamada bireysel bütünlük (tutarlık) duygusu, aile bütünlük duygusu ve benlik sayg1sı. Eğitimde Kuram ve Uygulama, 4(1), 19-30.

Çuhadaroğlu, F. (1986). Adolesanlarda benlik saygısı. Yayımlanmamış Uzmanlık Tezi, Hacettepe Üniversitesi Tip Fakültesi, Ankara.

Doğan, T. (2009). Bilişsel ve kendini değerlendirme süreçlerinin sosyal anksiyete açısından incelenmesi. Yayınlanmamış Doktora Tezi, Sakarya Üniversitesi Sosyal Bilimler Enstitüsü, Sakarya. 
Tekin Göçet, E., \& Doğan, T. (2014). The internal consistency reliability and construct validity of the Turkish translation of the beliefs about appearance scale. International Journal of Human Sciences, 11(1), 1178-1187. doi: $10.14687 /$ ijhs.v11i1.2910

Gençdoğan, B. (2001). Zung Depresyon Ölçeğinin lise ve üniversite öğrencileri için geçerlik güvenirliği ile faktör yapısı. Yayımlanmamıs doktora tezi, Atatürk Üniversitesi Sosyal Bilimler Enstitüsü, Erzurum.

Hart, T. A., Flora, D. B., Palyo, S. A., Fresco, D. M., Holle, C. ve Heimberg, R. C. (2008). Development and examination of the social appearance anxiety scale. Assessment, 15, 48-59.

Kline, R. B. (2005). Principles and practice of structural equations modeling. New York: Guilford.

Lindeman, M. ve Stark, K. (2010). Emotional eating and eating disorder psychopathology. Eating Disorders, 9(3), 251-259.

Marsh, H. W., Hau, K.T., Artelt, C., Baumert, J. ve Peschar, J. L. (2006). OECD's Brief self-report measure of educational psychology's most useful affective constructs: Cross-cultural, psychometric comparisons across 25 countries. International Journal of Testing, 6(4), 311-360.

Savaşır, I., Boyacıoğlu, G. ve Kabakçı, E. (1996). Bilisssel davranışı terapiler. Türk Psikologlar Derneği Yayınları, Ankara.

Schumacker, R. E., ve Lomax, R. G. (2004). A Beginner's Guide to Structural Equation Modeling. New Jersey: Lawrence Erlbaum Ass.

Simsek, Ö. F. (2008). Yapısal Esitlik. Modellemesine Giris: Temel İlkeler ve LISREL Uygulamalar. Ankara: Ekinoks Yayıncilik.

Spangler, D. L. (2002). Testing the cognitive model of eating disorders: The role of dysfunctional beliefs about appearance, Behavior Therapy, 33, 87-105.

Spangler, D. L., \& Stice, E. (2001). Validation of the beliefs about appearance scale. Cognitive Therapy and Research, 25 (6), 813-827.

Sungur, M. Z. (1994). Kognitif görüş bağlamında depresyon ve antisipasyon. Psikizatri, Psikoloji ve Psikofarmakoloji Dergisi, 2 (Ek-4).

Sümer, N. (2000). Yapısal eşitlik modelleri: Temel kavramlar ve örnek uygulamalar. Türk Psikoloji Yazllar, 3 (6), 49-74.

Tabachnick, B. G., ve Fidell, L. S. (2007). Using Multivariate Statistics (5. Bask1). Boston: Allyn and Bacon.

Young, J. (Ed.). (1994). Cognitive therapy for personality disorders: A schema-focused approach (2nd ed.). Sarasota, FL: Professional Resource Press. 